\title{
MATHEMATICAl ECONOMICS COMES TO AMERICA: \\ Charles S. PeIRCE'S ENGagement With Cournot'S \\ RECHERCHES SUR LES PRINCIPES MATHEMATIQUES DE LA \\ THÉORIE DES RICHESSES
}

\author{
BY JAMES R. WIBLE \\ AND KEVIN D. HOOVER
}

CHOPE Working Paper No. 2013-12

July 2013

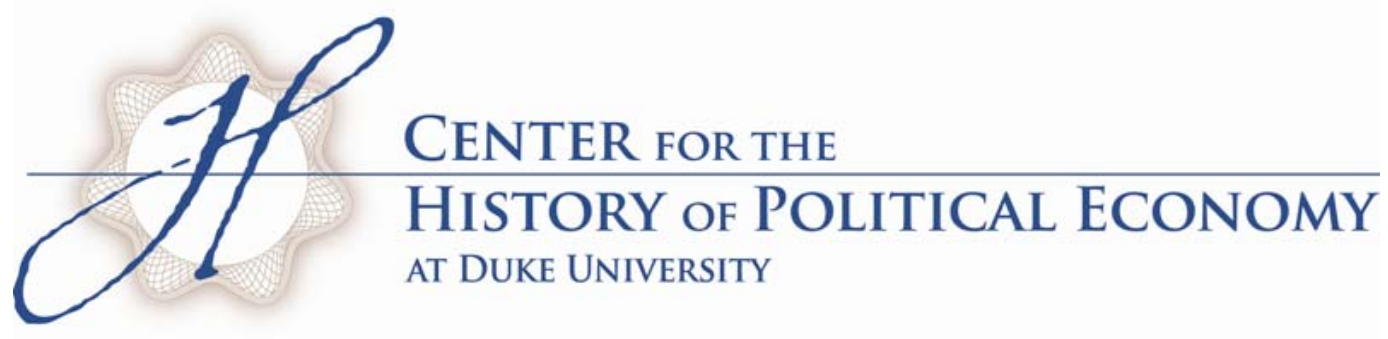




\title{
Mathematical Economics Comes to America: Charles S. Peirce's Engagement with Cournot's Recherches sur les Principes Mathematiques de la Théorie des Richesses*
}

\author{
James R. Wible† \\ and \\ Kevin D. Hoover‡ \\ †James R. Wible \\ Department of Economics \\ 10 Garrison Avenue \\ University of New Hampshire \\ Durham, New Hampshire 03824 \\ E-mail: Jim.Wible@unh.edu \\ $\ddagger$ Kevin D. Hoover \\ Department of Economics and Department of Philosophy \\ Duke University \\ Box 90097 \\ Durham, NC 27708-0097 \\ Tel. (919) 660-1876 \\ E-mail: kd.hoover@duke.edu
}

*We thank the participants in a workshop in the Center for the History of Political Economy at Duke University for helpful comments.

Revised, 18 July 2013 


\begin{abstract}
Although Cournot's mathematical economics was generally neglected until the mid1870s, he was taken up and carefully studied by the Scientific Club of Cambridge, Massachusetts even before his "discovery" by Walras and Jevons. The episode is reconstructed from fragmentary manuscripts of the pragmatist philosopher Charles S. Peirce, a sophisticated mathematician. Peirce provides a subtle interpretation and anticipates Bertrand's criticisms.
\end{abstract}

JEL Codes: B1, B13, B16, B31

Keywords: Charles S. Peirce, A.C. Cournot, mathematical economics, monopoly, duopoly, oligopoly, perfect competition 


\section{Mathematical Economics Comes to America: Charles S. Peirce's Engagement with Cournot's Recherches sur les Principes Mathematiques de la Théorie des Richesses}

\section{One Neglected Author Finds Another}

Charles Sanders Peirce (1839-1914) was a nineteen century American polymath. Peirce, the originator of pragmatism, is probably the greatest philosopher America has yet produced. He was the founder of semiotics and made major contributions to logic, the theory of probability, and empirical psychology. He was also a notable bench scientist, who as well as being credited with meticulous measurements of the brightness of stars and of the variations in the earth's gravity, made contributions to the metrology of astronomy and geodesy. And while Peirce’s pragmatism may have influenced American institutionalism, few economists or historians would recognize Peirce as an economist. Yet, in 1968 in their Prescursors in Mathematical Economics, William Baumol and Stephen Goldfeld included a letter of Peirce to Simon Newcomb that had been discovered and published by Carolyn Eisele (1957; also Peirce 1871c). Our knowledge of the context of Peirce's letter is fragmentary - mostly pieced together from the evidence of the letter itself, two other letters and some other clues.

Peirce and Newcomb were both members of the Scientific Club of Cambridge, Massachusetts, and some time toward the end of 1871, the club discussed political economy. Such clubs were a feature of the American intellectual milieu of the middle of the $19^{\text {th }}$ century - a time before specialization and professionalization divided intellectual society into neat compartments that discouraged trespassing and excluded amateurs. Simon Newcomb (1903, p. 243) describes the Scientific Club of Washington:

This was one of those small groups, more common in other cities than in Washington, of men interested in some field of thought, who meet at brief intervals 
at one another's houses, perhaps listen to a paper, and wind up with supper. . . The club was not exclusively scientific, but included in its list the leading men who were supposed to be interested in scientific matters, and whose company was pleasant to others.

Both Supreme Court Chief Justice Salmon Chase and General William Tecumseh Sherman, the scourge of the Confederacy, were members of the Washington Scientific Club.

Cambridge at mid-century was the center of American intellectual life. Peirce was born into a politically connected, intellectual elite. His mother, Sarah, was the daughter of the prominent United States senator Elijah Hunt Mills. His father, Benjamin Peirce, was a Harvard professor, an astronomer and, the premier American mathematician of his day. From his early childhood, the leading scientists and intellectuals of the day were frequent guests in the Peirce home. Various clubs added to the intellectual ferment of Cambridge. Charles Peirce was himself a central figure in the Metaphysical Club, memorialized in the title of Louis Menand’s (2002) intellectual history of American pragmatism. The Cambridge Astronomical Society was eventually transformed into the Mathematics Club under the leadership of Benjamin Peirce. By the early 1860s, Charles was a member and presented a paper on the four-color problem (Fisch 1982, p. xvii).

The Cambridge Scientific Club counted some of the stars of the midcentury’s intellectual firmament among its membership, including Benjamin Peirce, the naturalist Louis Agassiz, and Admiral Charles Henry Davis, who was the husband of Sarah Peirce's sister and, thus, Charles Peirce's uncle by marriage, as well as a former superintendent of the United States Naval Observatory and of the American Ephermeris 
and Nautical Almanac. Benjamin Peirce, Agassiz, and Davis were also three of the six founders (all Cambridge men) of the National Academy of Sciences. ${ }^{1}$

That a group of scientifically inclined Harvard men should take up political economy is hardly surprising - it was regarded as an important and relevant subject mid$19^{\text {th }}$ century America. Newcomb (1903, pp. 400-402) reports that his own serious study of political economy began when Thomas Hill, a mathematician and student of Benjamin Peirce's, who became president of Harvard in the mid-1860s, introduced him to Henry Carey’s Principles of Social Science (1858-1860). (Newcomb did not think highly of Carey, but was enthusiastic enough about economics to publish his own Principles of Political Economy in 1886.) It was not surprising that the Scientific Club studied political economy; what was surprising was exactly what they studied: Antoine Augustin Cournot’s Recherches sur les Principes Mathematiques de la Théorie des Richesses (1838). Cournot's Recherches was at once the most sophisticated mathematical treatment of economics extant and a book that had been largely ignored in the thirty-three years since its publication.

Cournot (1801-1877) was educated at the Ecole Normale Supérieure in Paris. ${ }^{2}$ After completing a doctorate in mechanics and astronomy, he obtained, with the sponsorship of the eminent French mathematician and physicist Poisson, the post of professor of analysis and mechanics in the University of Lyon. Subsequently, he turned to academic administration in Grenoble and Dijon. Cournot's voluminous works in mathematics (including a highly regarded book on the theory of probability) and the

\footnotetext{
${ }^{1}$ The others were the astronomer Benjamin Gould, Alexander Dallas Bache, Superintendent the U.S. Coast Survey, and Harvard classicist Cornelius Felton (National Academy of Science, undated).

${ }^{2}$ The details of Cournot's career are found Nichol (1938), Baumol and Goldfeld (1968, pp. 161-163), and Shubik (1987).
} 
philosophy of history and science were widely respected. Overall, his career was highly successful; yet, as an economist - as he himself clearly felt - he was a failure. Aside from desultory and typical negative remarks, Recherches appears to have influenced no economists before the 1870s. Thirty-six years after it first appeared it was reviewed in a French journal (de Fontenay 1864), having already received a relatively favorable review in a Canadian journal seven years earlier (Cherriman 1857; see also Dimand 1995, which reprints Cherriman's review as an appendix). Cournot's two later nonmathematical books on political economy were similarly ignored. ${ }^{3}$

Schumpeter (1954, p. 463) places Cournot among “The Men Who Wrote Above Their Time” - that is, men who delivered "important performances, the powerful originality of which was recognized late but which the profession completely, or almost completely, failed to recognize at the time.” Cournot's achievement was to reconceive economics as a mathematical discipline. “Mathematical economics” before Cournot was mainly a matter of quantifying simple relationships or turning verbal expressions into dispensable algebra. These efforts failed to exploit the resources of mathematics. In expressing economic relationships in general functional forms rather than with arbitrary concrete equations and then analyzing them with the tools of the differential and integral calculus, Cournot broke no new mathematical ground - the calculus was, after all, the bread and butter of his training as a physicist - yet such tools had never before been brought to bear on economics, and his book amounted to a complete reconceptualization of the field. In retrospect the Recherches proved to be a book "that for sheer originality

\footnotetext{
${ }^{3}$ Ekelund and Hébert (1990) argue that Cournot was better understood by his contemporaries than is typically portrayed and that, if he were neglected, it was in large part because of his personality and reluctance to engage his critics.
} 
and boldness of conception has no equal in the history of economic theory ...” (Blaug 1997, p. 301).

Cournot provided the first formal, systematic account of economics as centered on optimization problems. And he did so with great sophistication, analyzing second-order as well as first-order conditions for optima and accounting for corner solutions and fixed costs (e.g., Cournot 1838, pp. 61-62, pp. 56-57) . Although he does not use the current terminology, he derives the now-standard optimization rules: set output such that marginal revenue equals marginal cost, which reduces in perfect competition to set output such that price equals marginal cost. In analyzing demand, he clearly exposits the concept - though again not the current term - of the elasticity of demand. He provides the earliest example of comparative static analysis (Baumol and Goldfeld 1968, pp. 161163; Shubik 1987). And Cournot appears to have been the first to draw those workhorses of modern economic analysis, demand and supply curves, as well as the first to give them a general mathematical formulation (Blaug 1997, pp. 189, 283, 301-306; Humphrey 2010). ${ }^{4}$

On the conventional account, Leon Walras (1874a, b) - who probably knew of Cournot through his father, who had been Cournot's classmate - and William Stanley Jevons (1879, preface) rescued Cournot from obscurity. The dates are critical, because the Scientific Club of Cambridge, was reading Cournot three years before Walras's first mention of him in print and seven years before Jevons’s preface - and, in fact, a year before Jevons had even obtained a copy of the Recherches (Jevons 1879, p. xxxii). Jevons was an indifferent mathematician, and "Walras had only the instincts and none of the techniques of a mathematician” (Blaug 1997, p. 279). Jevons himself observes in his

\footnotetext{
${ }^{4}$ The terms “supply curve” and “demand curve,” however, are due to Flemming Jenkin (1870).
} 
preface: "Even now I have by no means mastered all parts of [the Recherches], my mathematical power being insufficient to enable me to follow Cournot in all parts of his analysis” (Jevons 1879, p. xxxii). Indeed, the fact that Baumol and Goldfeld identify no economist earlier than Peirce who rose to Cournot's level of mathematical sophistication perhaps by itself explains their inclusion of the letter to Newcomb in Precursors in

\section{Mathematical Economics.}

Its mathematical approach, which had proved a barrier to the appreciation of Cournot's Recherches for more than a quarter century, may have been one its attractions to the Scientific Club. Benjamin Peirce was the most prominent American mathematician of his day, Charles Peirce would subsequently become one of the founders of mathematical logic, and Benjamin Peirce’s protégé, Simon Newcomb - another member of the club - would later become the editor of the American Journal of Mathematics. Given their shared backgrounds in mathematics and astronomy, it is likely that both Peirces and Newcomb were familiar with Cournot's work on probability and science. Despite a paucity of reviews, the Recherches was frequently listed in advertisements, circulars, and catalogues, and it is not hard to imagine, however much he was ignored by the political economists of his day, that the members of the Scientific Club would have recognized that Cournot's approach played to their intellectual comparative advantage.

\section{What is in Cournot?}

A professionally trained economist ignorant of the history of his discipline would have severe difficulty in dating Cournot's Recherches - indeed, even in placing it in the right 
century. It strikes us as an utterly modern work - underlining Schumpeter's view of Cournot as a man above his time. It is not just that Cournot provides us with the nowstandard presentations of monopoly and perfect competition much as they are found in basic microeconomics textbooks today; it is that he presents them in a thoroughly modern idiom. The ideas of Smith, Ricardo, Jevons, Marshall, and Walras live on in modern economics, but the dust of an outmoded vocabulary and defunct styles of exposition hang around the original texts. Not so with Cournot. It would hardly raise a student's eyebrow if Cournot's text were included on a modern graduate syllabus. Cournot invented the modern idiom of mathematical economics and remains one of its master expositors. He did not attempt to write a complete treatise on political economy in the mode of Adam Smith. Rather - in the manner of so many recent economists - he extracted from political economy just those portions that were most amenable to mathematical representation and analyzed them concisely and efficiently. In style and substance, the Recherches reads very much like graduate textbooks from Samuelson’s Foundations of Economic Analysis (1947) to the present day.

As a mathematician reared in the tradition of Descartes, Cournot was equally at home with, and employed both, graphs and equations. With generations of microeconomics texts behind us, it would be easy to present the economic content of Cournot's work entirely in graphs. But that would miss a central historical point: Cournot's application of the formal machinery of the calculus to demand and supply was a milestone in the development of economics. To elide the mathematics would fail to give us the Cournot that so engaged Charles Peirce in 1871. 
Cournot's core contribution - found in Chapters IV, V, VII, and VIII of the Recherches - is to the analysis of competition. Cournot lays the groundwork of what we now call the theory of the firm or the theory of market structure.

Cournot's (1838, p. 47) first step is to postulate a downward-sloping market demand curve: ${ }^{5}$

$$
\begin{aligned}
& q=F(p), \\
& F^{\prime}(p)<0,
\end{aligned}
$$

where $q$ = the quantity of good demanded and $p=$ its price. (Note: Cournot and Peirce use different, but equivalent, notations. Throughout, even in direct quotation, we adopt a common, yet still different, notation - closer to that of Cournot than of Peirce - in order to ease the comparison and to aid the reader's recall of the meanings of the symbols. ${ }^{6}$ ) Cournot explicitly notes that demand depends on a variety of factors that he assumes are unchanging for purposes of the analysis and that, in any case, are too various to represent. He maintains that the demand curve cannot usefully be derived from deeper principles but is essentially an empirical relationship that might even be quantifiable. Nevertheless, in his most truly mathematical step, Cournot observes that useful analysis is possible even if the relationship is only qualitative:

for it is well known that one of the most important functions of analysis consists precisely in assigning determinate relations between quantities to which numerical values and even algebraic forms are absolutely unassignable. [Cournot 1838, p. 48]

\footnotetext{
${ }^{5}$ All references to the Recherches are to the 1927 edition of the 1897 English translation by Nathaniel T. Bacon titled Researches into the Mathematical Principles of the Theory of Wealth. It includes an introductory essay by Irving Fisher.

${ }^{6}$ The Appendix shows the mappings among Cournot's, Peirce's, and our notations.
} 
Cournot shows a mathematician's care for nuance and qualification throughout his exposition. Nonetheless, we shall stick to the main current of his analysis and leave it the reader to pursue the details independently.

Readers who already know modern microeconomics will find our exposition of market forms to be both familiar and elementary. But even these readers will benefit from seeing Cournot’s presentation as Peirce would have experienced it.

\section{MONOPOLY}

Cournot begins with the analysis of a single firm, a monopoly, and proceeds step by step to add firms until reaching "unlimited" competition. The analysis of monopoly is the linchpin of his exposition. He asks the reader to imagine a single producer of mineral water that is drawn directly from a natural spring and essentially faces no costs of production, so that the producer must consider only how to maximize his profits given market demand. But he rapidly moves on to consider a monopolist who also faces costs that vary with the amount produced. We start with that case. Gross receipts are simply $p q$, the volume of goods sold $(q)$ times the price $(p)$, which, substituting from (1), can be written as $p F(p)$. Net receipts or what we shall call profit (П) subtract off costs:

$$
\Pi=p F(p)-\Phi(q)
$$

where $\Phi()=$. the cost function. Cournot explores various possibilities for the shape of this function - that is, for the manner in which costs might vary with the amount of production.

The goal of the monopolist is to maximize profits. Cournot treats this initially as a matter of choosing the right price. Following the standard rules of calculus, he 
differentiates (2) with respect to prices and sets the result equal to zero to solve for a maximum: ${ }^{7}$

$$
\left[F(p)+p \frac{d F}{d p}\right]-\left[\frac{d \Phi}{d q} \frac{d F}{d p}\right]=0
$$

Cournot typically rewrites (3) as

$$
q+\frac{d F}{d p}\left[p-\frac{d \Phi}{d q}\right]=0
$$

Modern economists refer to the first term in square brackets in (3) as marginal revenue and the second as marginal cost - here the small additions to revenue and cost that would result from a small increase in the price of the good - so that (3) says that to achieve maximum profit, a monopolist should choose a price that sets marginal revenue $=$ marginal cost.

Figure 1 shows the monopolist's decision diagrammatically. The downwardsloping black curve is Cournot's demand function $F(p) .{ }^{8}$ The steeper, downward-sloping grey curve is marginal revenue $\left[F(p)+p \frac{\partial F}{\partial p}\right]$. And the upward-sloping grey curve is marginal cost $\left[\frac{\partial \Phi}{\partial q} \frac{d F}{d p}\right]$. (Here we draw the marginal cost curve as upward sloping at an increasing rate, though Cournot considers other shapes as well.) The profit-maximizing quantity is, then, $q^{*}$ - the quantity for which marginal revenue equals marginal cost.

\footnotetext{
${ }^{7}$ We take for granted, but Cournot actually checks, that the second-order conditions for a maximum are fulfilled.

${ }^{8}$ Cournot plots price against the horizontal axis and quantity against the horizontal axis. We, however, follow Alfred Marshall's practice - nearly universally adopted among modern economists - of price plotting price against the vertical axis and quantity against the horizontal axis. Marshall probably adopted this practice because he first considered supply and demand curves for perishable quantities, such as fish, in which a fixed quantity was offered in the market and prices adjusted to demand, so that price was the dependent variable. (See Blaug 1997, p. 382 for an alternative explanation.)
} 
That quantity will be demanded if the monopolist sets the price from the demand curve at $p^{*}$.

Cournot describes the monopolist as choosing the market price that maximizes profits, letting the market choose its demand at that price; but he is well aware that it is completely equivalent to describe the monopolist as choosing the quantity offered and letting the market set the price. When he wants to emphasize the second case he writes the demand function in the inverse form $p=f(q)$.

\section{DUOPOLY AND OLIGOPOLY}

Cournot introduces competition with a second producer. The market form with two producers is now called duopoly, although Cournot does not use that term. The total quantity produced is $q=q_{1}+q_{2}$, where the subscripts refer to producers 1 and 2 . Cournot assumes that each producer takes the output of the other producer as a fixed quantity and then acts as a monopolist with respect to the remaining market demand. Writing the demand function in its alternative form as a function of quantity rather than price, Duopolist 1 acting as a monopolist maximizes profit (2) by choosing a quantity to produce $\left(q_{1}\right)$ for which the analogy to equation $\left(3^{\prime}\right)$ holds: ${ }^{9}$

$$
f\left(q_{1}+\bar{q}_{2}\right)+\frac{d f\left(q_{1}+\bar{q}_{2}\right)}{d q} q_{1}-\frac{d \Phi_{1}\left(q_{1}\right)}{d q_{1}}=0,
$$

where the bar over $q_{2}$ indicates that Duopolist 1 takes the output of Duopolist 2 as fixed.

\footnotetext{
${ }^{9}$ The duopolist's problem is $\max _{q_{1}} \Pi=p q_{1}=f\left(q_{1}+\bar{q}_{2}\right) q_{1}-\Phi_{1}\left(q_{1}\right)$. The solution is found from setting the first derivative to zero: $f\left(q_{1}+\bar{q}_{2}\right)+q_{1} \frac{d f\left(q_{1}+\bar{q}_{2}\right)}{d q}-\frac{d \Phi_{1}}{d q_{1}}=0$.
} 
Duopolist's 1's analysis is shown in Figure 2, which is essentially the same as Figure 1, except that the duopolist takes the market demand curve to be shifted to the left by Duopolist 2's conjectured supply $\left(\bar{q}_{2}\right)$. Duopolist 2 would be willing to supply $q_{1}^{*}$.

Cournot says that Duopolist 1 will sell his desired supply

by properly adjusting his price, except as [Duopolist 2], who, seeing himself forced to accept this price and this value of $q_{1}$, may adopt a new value for $q_{2}$ than the preceding one” [Cournot 1838, p. 80]

Thus, even though Cournot analyzes the maximization problem for Duopolist 1 as one of choosing the correct quantity $\left(q_{1}\right)$ given a price and, so, characterizes the duopolist as a price-taker, he also regards the duopolist as a price-setter (quantity-taker) who must act with respect to price, even if he is constrained to follow the market. This is the direct result of his having reduced the problem of competition to one of monopoly, taking the quantities of other producers as given. The monopolist, as we have already seen, can be described indifferently as a price-setter or a quantity-setter.

Cournot imagines that Duopolist 2 solves mutatis mutandis the same problem as Duopolist 1, yielding the analogous first-order condition:

$$
f\left(\bar{q}_{1}+q_{2}\right)+\frac{d f\left(\bar{q}_{1}+q_{2}\right)}{d q} q_{2}-\frac{d \Phi_{2}\left(q_{2}\right)}{d q_{2}}=0
$$

There is no reason, however, to believe for any arbitrary assumption about $\bar{q}_{1}$ that Duopolist 2's optimal choice $q_{2}^{*}$ will coincide with the quantity that Duopolist 1 assumed that Duopolist 2 would supply $\left(\bar{q}_{2}\right)$. Cournot shows that there is a joint solution to (4) and (5). He constructs mathematically and graphically two curves (now referred to as reaction functions), which correspond to Cournot's (1838) Figure 2. For Duopolist 1, he chooses different assumed values of $\bar{q}_{2}$ and then solves (4) to obtain the optimal quantity 
supplied. The result is shown in by the heavy black curve in Figure 3. He constructs the analogous (light black) curve for Duopolist 2 for different assumed values of $\bar{q}_{1}$. The point at which the two cross is an equilibrium with the property that what each duopolist chooses as optimal is exactly what the other duopolist assumes it will choose: $q_{1}^{*}=\bar{q}_{1}$ and $q_{2}^{*}=\bar{q}_{2}$. At this equilibrium, neither firm has any incentive to change its output; each produces the right amount given what the other firm actually produces.

Cournot demonstrates that the duopolists together will produce a greater quantity at a lower price than either would if they could monopolize the same market.

Cournot is not completely clear about whether he regards the reaction functions as corresponding to the real-time behavior of duopolists when first beginning to compete or whether they are merely conjectural, with the equilibrium corresponding to a position in which neither duopolist has any incentive to alter production, without addressing how the duopolists were able to discover the equilibrium in the first place. He does, however, hint that a real-time process would be involved in resolving any deviation from the equilibrium:

if either of the producers, misled as to his true interest, leaves it temporarily, he will be brought back to it by a series of reactions, constantly declining in amplitude . . . [Cournot 1838, p. 81]

Imagine that after having been in equilibrium Duopolist 1 mistakenly supplies $q_{1}^{1}$ instead of $q_{1}^{*}$. Then, as shown in Figure 3, Duopolist 2 would respond with $q_{2}^{1}$ to which Duopolist 1 would respond with $q_{1}^{2}$, to which Duopolist 2 would respond with $q_{2}^{2}$, and so forth. Each step carries the duopolists closer and closer to the original equilibrium. The equilibrium is, then, stable - at least as drawn in Figure 3. Cournot explores the 
conditions under which this stability result will obtain more generally, and he shows that it depends on the precise slopes of the reaction functions.

\section{UNLIMITED COMPETITION}

Having established the solution for duopoly, Cournot goes on to analyze three, four, or more competitors in precisely the same way. Each competitor conjectures the output of the other competitors and then solves for its own optimal output in the manner of a monopolist. The necessity of pricing to market forces each competitor to revise its conjectures of the others' production until an equilibrium is established. Cournot argues that as the number of competitors becomes very large, a much simplified mode of analysis becomes possible. Unlimited competition (what modern economists refer to as perfect competition) obtains when each competitor becomes so small relative to the market as a whole that essentially the same equilibrium would occur whether or not any one of them was present. Once again, in keeping with the fact that he always treats producers as monopolists at heart and exploiting the equivalence of price-setting and quantity-setting for a monopolist, Cournot characterizes the unlimited competitor's choice on the analogy with equation (3') rather than with (4) or (5). For competitor $k$, the first-order condition is:

$$
q_{k}+\frac{d F}{d p}\left[p-\frac{d \Phi_{k}\left(q_{k}\right)}{d q_{k}}\right]=0
$$

Cournot defines a firm to be small enough to be an unlimited competitor when the amount that it produces is "inappreciable" in the sense that effectively

$$
f\left(q-q_{k}\right)=f(q)=F^{-1}(q) \text { and } \frac{d f\left(q-q_{k}\right)}{d q}=\frac{d f(q)}{d q}=\frac{d F^{-1}(q)}{d q} \text {. In words, producer } k \text { 's }
$$


output is so small that it affects neither total output nor the slope of the market demand curve. When this is true, $q_{k}$ in (6) can be set to zero to yield a simpler relationship:

$$
p-\frac{d \Phi_{k}\left(q_{k}\right)}{d q_{k}}=0,
$$

which is the well-known rule in modern microeconomics: the perfect competitor maximizes profits when it chooses its level of output such that price $=$ marginal cost .

Cournot notes that if we add up the solutions for $q_{k}$ in (7) for each competitor, we get a function relating quantity to price, which he names $\Omega(p)$. This function is the horizontal summation of each of the marginal cost curves in Figure 3 for the numerous tiny competitors of unlimited competition. It is, historically, the first description of a market supply curve (Humphrey 2010, pp. 29-30). The relationship between prices and quantities “can be written in a very simple form” (Cournot 1838, p. 91):

$$
\text { supply }=\Omega(p)=F(p)=\text { demand } \text {. }
$$

The equality of supply and demand determines the market price for the good, and each competitor chooses to supply the amount that makes its marginal cost equal to that market price, according to (7).

Cournot's analysis of market structure and its mathematics is considerably more elaborate and nuanced than the core results presented here. And he uses this analytical framework to address various substantive questions in economics and economic policy. What we have presented is nonetheless the heart of the analysis and all that we will need to place Peirce's reading of Cournot into context. 


\section{Peirce Reads Cournot}

DECEMBER 1871

Peirce's chapter in the history of economics opens in media res. It is the week before Christmas 1871. Peirce is alone at his desk in Washington, D.C. wrestling with Cournot and reaching out to his family and friends by letter.

As well as professor of mathematics and astronomy at Harvard, Benjamin Peirce was the Superintendent of the United States Coast Survey. In the days before the reform of the civil service and the institution of rules against nepotism, it raised few eyebrows that he appointed his son Charles to the post of temporary assistant in charge of the Coast Survey office and, subsequently, assistant in charge of gravimetric experiments (Brent 1998, pp. 89-90). The Coast Survey was based in Washington, D.C. and Benjamin needed a trusted set of eyes in the office that he ruled from Cambridge. In 1871, Peirce fils divided his time between Cambridge and Washington. He had not yet moved his wife to the capital. (When she finally did move, she found that she disliked Washington so intensely that she wrote a scathing article about it for the Atlantic Monthly (Brent 1998, p. 92).)

We know nothing directly about the discussions of Cournot in the Scientific Club. We do know that the club was scheduled to meet on 28 December to hear Benjamin present a paper on political economy. Earlier in the month, he had engaged Charles to prepare some graphs, mostly like for the talk (Fisch 1999). It is possible, but uncertain, that Charles - perhaps home for the holidays - attended the meeting. ${ }^{10}$ But what exactly

\footnotetext{
${ }^{10}$ Fisch (1999) indicates that the meeting was attended by [Joseph] Winlock, Dixwell, [Charles] Eliot (then president of Harvard),] Lovering, Walker, and [Francis] Bowen (teacher of philosophy and political economy at Harvard), as well as Peirce. The first names in square brackets are conjectures based on general knowledge of the Harvard/Cambridge intellectual milleau in the 1860s and '70s, as described inter alia in Brent's (1998) biography of Charles Peirce. It is not clear whether Peirce refers to Benjamin, who
} 
Benjamin said has been lost to time. We do know that Charles was deeply immersed in Cournot. Two complete letters, a part of another, and a manuscript fragment are all of our evidence - a small, yet telling resource.

The manuscript fragment, "Calculus of Wealth,” (Peirce 1871a) is written in Cournot's characteristic idiom. Peirce considers the situation of a single producer. He does not identify the producer as a monopolist, and issues of market structure arise only at the end of the fragment. Peirce derives the profit-maximizing level of output essentially, equation (3) - checking both first-order and second-order conditions. Peirce refers to the first-order condition (3) as "the equation of wisdom.” This quaint terminology signals an important element of Peirce’s conceptualization of the economic problem. Optimization is not to be interpreted principally descriptively, but normatively, and we cannot rule out the possibility of deviations from "wisdom."

Much of the rest of the fragment is devoted to exploring the mathematical possibilities of the cost function $\Phi(q)$. Here, Peirce covers ground previously explored in Cournot's Recherches. In particular, although Peirce expresses it in terms of first-, second-, and third-derivatives rather than graphically, he suggests that cost curves will generally take a shape as in the left-hand panel of Figure 4: rising at a decreasing rate, flattening, and ultimately rising at an increasing rate. He analyzes the effect on price of an increase in costs and, as Cournot, concluded that an increase that did not change the slope of the cost curve - that is one that shifted $\Phi(q)$ without altering $\Phi^{\prime}=\frac{d \Phi}{d q}-$ does not change the optimum. The point is that the profit-maximizing rule is the solution to the

was certainly there, or Charles. Walker may have been either Amasa Walker, who was an economist, or his son Francis Amasa Walker, who was later president of the Massachusetts Institute of Technology and the first president of the American Economic Association. At this point, we have been unable to identify the full names of Lovering or Dixwell. 
problem, at what point does adding one more unit of production add more to costs than to revenues? - for that problem, what matters is not the total costs but the marginal costs or what Peirce elsewhere refers to as "final costs."11 Generally, Cournot worked directly with the final cost function, Peirce's version of which is displayed in the right-hand panel of Figure 4.

Peirce notices that a "fixed tax" - that is, one that is levied on the producer irrespective of the level of output - adds to cost, but not to final cost, and, therefore, does not change the production decision but "falls wholly on the producer."

Generally, both Cournot and Peirce conclude that final prices will fall for some time as production begins to increase and, ultimately, will begin to rise steeply. The falling segment is the typical case for manufacturing industries, which may or not turn up at a relevant level of production; an ultimately rising segment is inevitable in agriculture and mining. Cournot notes, though Peirce does not, that a falling final cost curve promotes monopoly or at least a tendency toward monopoly (Cournot 1838, p. 91). Peirce concludes that increases in final cost will increase price. (In Figure 1 consider the effect on price of shifting the marginal cost curve upward).

Peirce also analyzed shifts in demand. An increase in demand that kept the slope of the demand curve unchanged (a parallel shift of the demand curve in Figure 1, which would result in a parallel shift in the marginal revenue curve) would "almost universally" raise price. Peirce qualifies the result, because it is possible that costs fall so steeply that

\footnotetext{
${ }^{11}$ Peirce (1874), where he also refers to "the cost of production of the last unit." Peirce may have adopted usage of "final" to refer to the last unit or margin from Jevons (1871), who frequently refers to the "final degree of utility," "final yield," "final increments," and "final ratios," using "final" in the same sense as modern economists use "marginal." A similar usage is not found in Cournot and does not appear to be adopted from contemporaneous calculus texts.
} 
an increase in demand could lower price (Figure 5). A steepening of the demand curve would reduce price.

Most of the "Calculus of Wealth" considers a single producer, but Peirce ends with some suggestive thoughts on the "the relations of different producers." Competition is an instance of relations between producers’ prices. “[T]heir making things that can be used together" - bread and butter or needles and thread, perhaps - is an instance of “concourse,” or what modern economists call complementarity in consumption. $^{12}$

Peirce suggests that Cournot has taken an overly narrow approach to competition, having "overlooked ... a competition between different kinds of articles which can be put to the same use.” Cournot "considered only the case in which all the prices must be the same.” Peirce seems to suggest the foundations for what was later referred to as monopolistic competition: goods that are not identical but serve overlapping needs compete on price, yet do not have to have the same price. Unfortunately, the fragment breaks off at this point, and we are left with only a tantalizing suggestion.

Cournot's analysis of competition appears to have worried Peirce and in the week before Christmas he addressed it in two letters with very different tones - one to his father and one to Newcomb. The letter to his father is dated later than the one to Newcomb, yet logically the issues that he raises in it are prior to those he addressed to Newcomb.

\footnotetext{
12 Another example of the sophistication of Peirce's economic thought. The modern terminology of substitutes and complements came later, and few economists had even hinted at the relevant concepts at this point. Some exceptions are: Cournot (1838, ch. 9) himself, who clearly had the notion of complementarity in production; Isnard (1781) hints at both the concepts of substitution in consumption; and Menger (1871, p. 15), who had the concept of complementarity in consumption (complementäre Güter). We thank Jean Magnam de Bornier, Torsten Schmidt, and Richard van der Berg for these references.
} 


\section{To Benjamin PeIRCE: Cournot AND DuOPOLY}

As did Cournot, the letter to his father, Peirce (1871d) begins with the analysis of duopoly under the assumption that costs are zero. In keeping with his "equation of wisdom” in the "Calculus of Wealth,” Peirce retains Cournot's approach for a monopolist and treats each producer as a price setter. The first-order conditions for profit (in this case equivalent to revenue) maximization are the analogues to ( $\left.3^{\prime}\right)$ with $\Phi(q)$ set to zero:

$$
\begin{aligned}
& q_{1}+\frac{d F}{d p_{1}} p_{1}=0, \\
& q_{2}+\frac{d F}{d p_{2}} p_{2}=0,
\end{aligned}
$$

where the subscripts refer to the two duopolists.

Peirce argues that Cournot has not adopted the only way to think about the behavior (the "wisdom”) of competitors. In particular, he objects to Cournot's assumption that each duopolist conjectures that the output of the other is fixed. As Cournot acknowledges, the competitors have to set prices and, when goods are identical, they cannot set prices that are different from each other. But this, of course, is what they must be doing conjecturally (or, perhaps, Cournot assumes also in real life) as they converge on his duopoly solution as shown earlier in Figure 3. Peirce argues that the competitors will, in fact, always set the same price, which leads to two possibilities. First, if each seller reflects "that if he puts down his price, the other will put his down just as much . ..” then there is no reason to think that either can gain market share through 
price competition. $^{13}$ In this case, he argues that the duopolists would adopt the monopoly solution, essentially solving equation ( $\left.3^{\prime}\right)$. He does not explain how he thinks that they will reach this solution should they not start there nor how they would divide market share once they had arrived at the optimum. Perhaps Peirce would rely on Cournot's assumption that the competitors are identical to divide the market evenly between them. Had he investigated the more general case involving costs and followed Cournot (1838, pp. 85-87) in allowing that firms might be subject to different cost functions, he would have been forced to face the lacuna in his argument.

The second possibility is that competitors do not reason themselves into holding prices constant but, instead, always match the other competitor's price. They would be forced to do so, because no buyer would pay the higher price for the same good. Thus, "wisdom" to a competitive duopolist would amount to seeing that "if his price is lower than the other man's he gets all the customers besides attracting new ones.” He claims that Cournot's solution is inconsistent: Cournot's duopolist acts as if "in putting down his price [he] expected to get all the new customers and yet didn’t expect to get any of the other seller's customers. . ” Peirce makes the exact opposite assumption, that if one seller's price is lower, it will get all the other's customers: Mathematically, the demand for Duopolist 1's product is

$$
\frac{d F}{d p_{1}}=-\infty
$$

\footnotetext{
${ }^{13}$ Comparison of the holograph of Charles Peirce's letter to Benjamin Peirce reveals that in Eisele's (1976, p. 553) printed version a " $y$ " (i.e., $q$ in our common notation) is missing so that the expression $\frac{y_{1}}{y}$, which is Duopolist 1's share of the total sales, is rendered as $\frac{1}{y}$, which makes no sense in context.
} 
Graphically, the demand curve as seen by the individual duopolist is horizontal. Of course, the situation looks just the same to Duopolist 2, and, according to Peirce, "the price is forced down to zero, by successive action of the two sellers.”

Perhaps Peirce too is one of Schumpeter's men above their times - at the least, he is a man ahead of his time. Peirce's criticism of Cournot's duopoly model completely anticipates Joseph Louis François Bertrand's (1883) attack on Cournot, both for preferring a collusive solution in which producers divide the monopoly production among themselves and for arguing that the alternative is a spiral towards zero prices (and no production). Bertrand's criticism of Cournot appeared in a book review and was informal. It was, however, extremely influential. Along with the notice of Jevons and Walras, it both cemented Cournot's place in the history of economics and ensured that Cournot's analysis of duopoly would be rejected. ${ }^{14}$

By early in the $20^{\text {th }}$ century, the solution to the duopoly (or more generally, the oligopoly) problem was widely regarded as indeterminate, though Cournot's approach was revived in the 1920s (Schumpeter 1954, p. 983). Cournot's characterization of the oligopolists' equilibrium was later seen to be a case of the Nash equilibrium of game theory, so that one sometimes reads of Cournot-Nash equilibrium (see Daughety 1988, introduction). Nash equilibria are often not unique, and in any case there are usually

\footnotetext{
${ }^{14}$ Schumpeter (1954, pp. 982-983) acknowledges that Cournot's solution was widely rejected: "By the end of the century, there was, among the leaders, only Wicksell left to defend it.” Yet, although he believes (incorrectly, as we have seen) that "Bertrand was ... the first to make an attack upon it that challenged it on principle ...." he nonetheless characterizes Bertrand as having challenged it "so inadequately that I doubt whether it would have made much impression if Marshall, Edgeworth, Irving Fisher, Pareto, and others had not, though wholly or partly for other reasons, repudiated Cournot's solution.” It is hard to know what tips the balance of peoples' judgments, but we do know a number of economists in the $19^{\text {th }}$ and early $20^{\text {th }}$ centuries cite Bertrand as decisive against Cournot and that Edgeworth (1889, p. 501) justifies his dissent from Cournot's account of duopoly in part with reference to Bertrand: "I should have hesitated to assert that Cournot has made some serious mistakes in mathematics applied to political economy, but the authority of the eminent mathematician Bertrand may be cited in support of that assertion.”
} 
alternative possible equilibrium concepts that can be applied to games. At a minimum, then, Peirce and Bertrand both saw that Cournot had not definitely resolved all the issues involved with oligopoly.

Although Peirce appears to have completely anticipated Bertrand's criticisms of Cournot by a dozen years, there is a remarkable difference in tone. Bertrand's review is dismissive and treats Cournot as somewhat foolish. Peirce is inquiring and still trying to work out how one ought to look at the matter. The fact that his correspondent is his father may also account for the tentative air of his investigation. At various points, he asks, “Am I not right?” and "is this not a fact?”, as if he is ready to be told that he has looked at the matter wrongly or made some mathematical error. And he ends the letter, not in triumph, but with an odd puzzle posed in a postscript:

What puzzles me is this. The sellers must reckon (if they are not numerous) on all following any lowering of the price. Then, if you take into account the cost, competition would generally (in those cases) raise the price by raising the final cost.

What are we to make of his counterintuitive claim that competition can raise prices? It is impossible on such limited evidence to be sure, but some of the considerations of the "Calculus of Wealth" may suggest a plausible interpretation. Peirce suggested that, commonly, final cost curves slope downward for part of their range and that, if they slope downward strongly enough, a monopolist might lower its price in the face of an increase in demand. Recall that Peirce's solution to the duopoly problem is that the duopolists maximize joint profits at a common price and somehow divide the market between themselves. Consider a monopolist with the requisite steeply falling final cost curve, who has established the monopoly price, and compare the situation to a pair of identical duopolists with precisely the same final cost curves as the monopolist, 
which have also reached a joint profit-maximizing equilibrium. If the duopolists each took half the market, then each would produce on their final cost curves at a point half way between the joint optimal production and the origin. Since the curves are falling, each of their final costs must be higher than that for a monopolist with an identical final cost curve. The monopolist's marginal revenue, which had been exactly equal to its final cost, must now be too low to meet the duopolists higher final costs. The monopoly price would, therefore, imply a loss that can be made up at the margin only by the monopolist's adopting a higher price.

There is, perhaps, still a puzzle with this interpretation. The situation of the duopolists is formally similar to the situation of a monopolist with a steeply falling final cost curve faced with an fall in demand, as a monopolist supplies the whole demand and duopolists divide the market. Yet, in “Calculus of Wealth,” Peirce says, as we already noted, that an increase in demand "almost universally” increases price, and one would assume then that a decrease of demand would almost universally decrease price. But in analyzing duopoly he assumes that competition can be analyzed as formally equivalent to a fall in demand and yet that it is a price increase that typically follows.

\section{To Simon Newcomb: The LAw of Supply and Demand}

On Sunday 17 December, two days before his letter to his father, Peirce wrote to his wife, “Simon Newcomb came to see me today,” and Peirce’s biographer interpolates “they discussed political economy” (Peirce 1871b; Brent 1998, p. 89). ${ }^{15}$ Evidently, the conversation had not concluded to Peirce's satisfaction, for he followed it up on the same day with a letter to Newcomb (Peirce 1871c). It has none of the diffident tone of his

\footnotetext{
${ }^{15}$ On Newcomb, see Archibald (1924), Campbell (1924), and Moyer (1992).
} 
letter to Benjamin Peirce. Rather Peirce writes in the confident vein of a man trying to win a point or educate a student.

Evidently Peirce had asserted to Newcomb that the law of supply and demand held only in the case of unlimited competition. Note the singular; Peirce takes there to be a single law and not two distinct laws:

I take the law to be, that the price of an article will be such that the amount the producers can supply at that price with the greatest total profit, is equal to what the consumers will take at that price.

This is not the most felicitous of definitions, but its meaning seems clear enough. The law of supply and demand would not then hold for a monopoly; for the firm maximizes its profit (as in Figure 1) at the point that marginal revenue equals marginal (or final) cost, and if the good were priced at that margin, demand would far exceed profitable supply. It is that fact that permits the monopolist to charge a price above final cost.

Later Peirce amplifies the definition:

If the law of demand and supply is stated as meaning that no more will be produced than can be sold, then it shows the limitation of production, but is not a law regulating price.

Peirce's point is that there is no simple mapping in, say, the case of monopoly that would permit a clear partition between factors independently governing supply and those governing demand, even though the optimal price can be determined based on the demand and cost curves. His aim is to convince Newcomb that just such a simple mapping exists when competition is unlimited.

For Peirce, exactly as for Cournot, competition is unlimited when "nothing that any individual producer does will have an appreciable effect on the price; therefore he simply produces as much as he can profitably.” To demonstrate how the law of supply and demand emerges in unlimited competition, Peirce considers a single producer facing 
a fixed price, which we (as always translating to a common notation) call $\bar{p}$. Price is not a choice variable, so the condition for maximizing profit is to choose $q$ subject to a firstorder condition - essentially the same as equation (7):

$$
\bar{p}-\frac{d \Phi(q)}{d q}=0
$$

except that the bar over $p$ indicates that price is fixed. Contrast this case to one in which the same producer chooses its price, for which the first-order condition is identical to $\left(3^{\prime}\right)$ :

$$
q+\frac{d F}{d p}\left[p-\frac{d \Phi}{d q}\right]=0
$$

When competition is unlimited, the producer cannot affect the market price at all: "if the producer . . . lowers the price below what is best for him there will be an immense run upon him $\left[\frac{d F}{d p_{1}}=\infty\right] \ldots$. and "if he raises it above that he will have no sales at all, so that $\frac{d F}{d p_{1}}=-\infty$." Peirce does not note it explicitly, but the logic of lowering prices is identical to the point that he made in his letter to his father; namely, that since any cut in prices would be matched by all competitors, no producer could actually expect to capture market share in this manner and hence would be unwilling to start down the price-cutting path. When the price is constant, (13) reduces to (12). ${ }^{16}$

Peirce worries that his fellow mathematician Newcomb will regard his derivation as a sleight of hand. "If this differentiating by a constant seems outlandish, you can get the same result in another way.” He does not elaborate; but, of course, Cournot did get

\footnotetext{
${ }^{16}$ To see this, multiply both sides of (13) by $\frac{d p_{1}}{d F}$ to yield $\frac{d p}{d F} q+\left[p-\frac{d \Phi}{d q}\right]=0$; then since $\frac{d F}{d p_{1}}=\infty$ implies
} $\frac{d p_{1}}{d F}=0$, so the first term drops out to yield (12). Since we are consider one producer, variables with or without subscripts are the same; and since prices are constant, prices with and without a bar are the same. 
the same result, simply by asserting that the effect of any one producer in unlimited competition is so small that (12) does not differ materially from the same equation with $q$ set to zero; the collapse to (11) follows immediately.

Peirce's exposition of the case differs from Cournot's in an important respect and is distinctly modern. Peirce, in effect, draws a distinction between the market demand curve, which is downward-sloping, and the individual demand curve, which is horizontal (the graphical meaning of $\frac{d F}{d p_{1}}= \pm \infty$ ). Market supply and demand sets the price in unlimited competition (see Figure 6), and this price determines the location of the individual producer's horizontal demand curve. ${ }^{17}$ The individual producer's only choice is how much to produce. The producer is now a price-taker and a quantity-setter.

Thus, in unlimited competition price is determined as the intersection of independent supply and demand curves. Peirce does not reiterate, but obviously endorses, Cournot's understanding of the market supply curve as the horizontal summation of the final (i.e., marginal) cost curves of the individual producers. He does not state this explicitly. After all, he has written a letter as part of larger discussion, not an academic paper, and in any case as he notes in the postscript: “This is all in Cournot.”

A common reading of Cournot sees him as beginning with a price-setting monopolist, but as switching abruptly from price-setting to quantity-setting behavior as he moves to duopoly and other degrees of oligopoly. This is, however, not the way that we have presented Cournot in section 2. Rather we have followed Peirce's reading of Cournot. Peirce interprets Cournot’s analytical strategy for all forms of competition as

\footnotetext{
${ }^{17}$ Blaug's (1997, p. 43) attribution of the horizontal individual demand curve to Cournot appears to be reading back modern practice onto an earlier author. Although, as Peirce shows, that interpretation is completely consistent with Cournot's analysis, Cournot does not in fact present explicate perfect competition with that device.
} 
making assumptions to reduce the individual producer's problem to a monopoly problem that can be described either as setting prices or setting quantities. Thus, in the case of duopoly, Cournot assumes that a producer takes the quantities supplied by the other producer as given, and then solves the ordinary monopoly problem. As his criticism of Cournot in the letter to his father shows, Peirce was well aware that Cournot's strategy could be problematic. Nonetheless, in the letter to Newcomb he runs with it.

Peirce's interpretation of Cournot's strategy, which we believe to be correct, sheds light on what Baumol and Goldfeld (1968, p. 185) regard as an error in his letter to Newcomb. They note that Peirce states, “Clearly, $x>X$ because $D_{x} y<0$.” (Here, we retain Peirce's original notation, which translates into $p>\bar{p}$, because $\frac{d F}{d p}<0$ in our common notation.) Baumol and Goldfeld reject Peirce’s conclusion, which they gloss as “monopoly price greater than competitive price,” on the ground that it works only if $D_{y} z$ (our $\frac{d \Phi}{d z}$, the marginal cost for the producer) is the same for a monopolist and a competitive firm, which they deem to be "unlikely.” We believe that Peirce has made no such mistake.

Misled perhaps by the fact that Peirce's optimization rules apparently take the same form as those for monopolists and perfect competitors, Baumol and Goldfeld read Peirce's point as a comparison between monopoly and competition. But that is not what he actually says. Rather he simply compares a single producer in the same, but unspecified, market structure faced either with a fixed price ( $X$ or $\bar{p})$ - in which case, it is necessarily a quantity-setter - or with the flexibility to set its own price should wisdom point that way. 
It is obviously wrong that every fixed price that is admissible in the sense of yielding positive profits is necessarily less than the profit-maximizing price. So, it seems likely that what Peirce had in mind was a comparison between a price fixed at the point at which the $\frac{d \Phi(q)}{d q}$ (the marginal cost curve) crossed the demand curve with the price that would be set freely by the same producer facing the same demand curve. On that interpretation, Peirce is correct: the freely chosen price would be higher, precisely because the demand curve is downward sloping through that point.

It is true that, if a monopolist and a perfect competitor had the same cost structure, then it would follow from Peirce's analysis that monopolists would charge a higher price. As we pointed out in our discussion of the "Calculus of Wealth" and his letter to his father, Peirce did not typically assume that the monopolist and perfect competitor would, in fact, share the same cost structure. And the point of the letter to Newcomb is not to make such a comparison, but instead to establish that only the perfect competitor has a well-defined supply curve. In fact, Peirce never uses the word "monopoly" in the letter, even though it was a well-known term, and he draws a comparison not between a single producer and multiple producers, but rather between "what can be profitably produced at a certain price" and "the price ... the producer will set ... that will make [profit] a maximum ...” Only after drawing this latter contrast, does Peirce even introduce the notion of unlimited competition into the analysis.

Did Peirce win his point with Newcomb? We simply do not know. But we do know that in a review of Jevons's Theory of Political Economy published four months after Peirce's letter, Newcomb writes with admiration of Cournot: 
If we compare Professor Jevons's work with that of Cournot on the same subject, published more than thirty years ago, we cannot but admit that in fertility of method and elegance of treatment it falls far below it. But the latter can be understood only by an expert mathematician and the number of those who are at the same time mathematicians and economists is too small even to perpetuate the knowledge of such a work, so that even in this age Cournot has met the fate of the Atlantides. Hoping that he will be exhumed and his investigations continued by some future generation ... [Newcomb 1872, pp 435-436] ${ }^{18}$

Yet, Newcomb did not choose to rise to the challenge of exhuming and continuing the work of Cournot. His own Principles of Political Economy (1886) are innocent of Cournot and his mathematical approach. A few lines of algebra in the passages devoted to the quantity theory of money and some illustrative numerical tables are the extent of the mathematics. Equally, there is no trace of Peirce's subtle argument that the law of supply and demand holds only in the case of unlimited competition. Although nodding to Jevons in a terse discussion of diminishing "final [marginal] utility,” Newcomb’s book is, in fact, classical in conception - more in the mode of David Ricardo or John Stuart Mill than of Jevons, much less of Cournot or Peirce (Newcomb 1886, pp. 202-203). Was Newcomb old-fashioned? Or did he fear the fate of the Atlantides?

\section{THE FUtURE OF Political ECONOMY}

In December 1871 Peirce was clearly trying to understand Cournot - probably for the first time. He writes sometimes diffidently, sometimes confidently, but always with sophistication about the issues of market structure. While these forays do not exhaust Peirce's engagement with political economy, we have evidence of his returning to the core material of Cournot only twice - once in a letter written about a year later and again

\footnotetext{
${ }^{18}$ The Atlantides is another name for the Pleiades, the seven daughters of Atlas and Pleione in Greek mythology. According to the story Zeus turned them into the eponymous constellation when, after seven years fleeing Orion, they killed themselves. Orion, also a constellation, continues to pursue the Pleiades across the winter's night sky.
} 
in some manuscript fragments another eighteen months after that. The letter and fragments provide glimpses of Peirce's more seasoned reflections on the issues raised by Cournot.

Abraham Conger - apparently a lawyer from upstate New York - had written to Peirce inquiring about a supposed publication applying calculus to psychological or moral problems. In his reply to Conger, dated 3 or 4 January 1873, Peirce (1873) denies having done so: "I do not think that in the present state of our knowledge that anything useful could be done in that direction.” Peirce distinguishes economics from psychology and ethics and, at the same time, implicitly expresses dissatisfaction with Cournot and his own preliminary investigations: "I think, however, that a proper application of the Calculus to Political Economy, which has never yet been made, would be of considerable advantage in the study of that science” (emphasis added). Such a calculus would have three fundamental equations: the first relating cost and of output (i.e., a cost curve), the second relating sales and prices (i.e., a demand curve), and the third expressing "the principle by which the dealer is guided in fixing his price.”

Peirce’s three equations do not differ from his analysis of December 1871. In fact, he repeats (in a new notation) Cournot's profit-maximization rule (equation (3)) as the principle guiding a "wise" dealer. What is new is that Peirce acknowledges that "the most prominent phenomena of buying and selling require us to take account of the deviations of conduct from this condition of perfect wisdom.” Peirce cites the example, already worked out in his letter to his father, that a foresighted producer would understand that price cutting would be matched by its competitors and would, therefore, 
not produce the gains suggested by the direct application of (3). ${ }^{19}$ This is an example of a deviation from a particular rule; yet as Peirce presents it - both here and in the letter to his father - it would appear not to illustrate deviation from wisdom, but bowing before the claims of a higher wisdom. Nonetheless, Peirce has now distinguished between his hitherto normative account and a new empirical approach:

To discover and express in mathematical language the principles upon which dealers really act, would form an investigation which I should suppose was possible to be carried out, and which would be of considerable utility.

His empirical attitude may explain why he was so critical of Cournot's analysis of duopoly in the letter to his father and yet never adopted the contemptuous attitude of Bertrand.

The two manuscript fragments of 21 September 1874, titled by the editors of the Writings of Charles S. Peirce as “On Political Economy” (Peirce 1874) are mainly a repetition and elaboration of the analysis in the mode of Cournot already found in the writings of December 1871. In particular, the comparative statics of the "Calculus of Wealth” (Peirce 1871a) are worked out mathematically. Peirce reexamines the optimization problem, including both first-order and second-order conditions, and he conducts various comparative static exercises, including changes in the "sensitiveness of the market" (i.e., the elasticity of demand) - again under the assumption that sellers are “absolutely wise.” He extends those investigations into a consideration of discontinuities in demand and final cost. ${ }^{20}$ He also begins an investigation of what we would now refer to as substitutes and complements: “The desirability of a thing depends partly on the

\footnotetext{
${ }^{19}$ Peirce attributes this insight to Charles Baggage (1835).

${ }^{20}$ Instead of starting with total cost as previously, here Peirce works directly with "the Cost of production of the last unit" - that is, with what he previously referred to as "final cost" and that we know as marginal cost.
} 
possession of other things which are related to it in this respect either as alternative [substitute] or as coefficient [complement].” Peirce also states - probably for the first time in the history of economics - the requirement that preferences be transitive. Here, Peirce goes beyond Cournot, who took the demand function as a brute fact not subject to further analysis. We will take up Peirce's treatment of demand in a future paper.

\section{Peirce's Engagement with Economics}

Unlike Newcomb, who can be considered a professional economist, as well as an natural scientist, Peirce never contributed in any systematic way to the development of economics. Yet, throughout his career he kept up with developments in economics and used economic analysis to inform his approach both to natural science and to the philosophy of science. In 1877 he published an advanced mathematical economic analysis of the economics of research, with a detailed worked example of the optimal distribution of effort across alternative research strategies applied to gravity measurements. He wrote a popular, nonmathematical, but deeply informed analysis of the sugar tariff in 1884. And his work in other areas is suffused with economic examples and the insights born of a deep understanding of economics. He was also a trenchant critic of the way that - especially normative - economics developed in the later $19^{\text {th }}$ century. The current paper is part of a larger project on Peirce’s engagement with economics in which we will address both his particular applications of economic analysis and the influence of economics on his philosophical thought. 


\section{Appendix. Notational Conventions}

Peirce and Cournot use different notational conventions, both for defining variables and functions, and for operators used in the differential calculus. Their different usages have been translated in this paper (except where otherwise noted) into a common notation. Table A.1 shows the correspondences among the three systems with respect to the names of variables and functions.

Table A.1

Correspondences of Variable and Function Names

\begin{tabular}{rccc}
\hline \hline Concept & $\begin{array}{c}\text { Common } \\
\text { Notation }\end{array}$ & Cournot & Peirce \\
\hline quantity & $q$ & $D$ & $y$ \\
fixed quantity & $\bar{q}$ & & $x$ \\
price & $p$ & & $X$ \\
fixed price & $\bar{p}$ & net receipts & \\
profits & $\Pi$ & $F(p)$ & $x$ \\
demand function & $F(p)$ & $f(q)$ & $z$ \\
cost function & $f(q)$ & $\phi(q)$ & \\
inverse demand fupply function & $\Phi(q)$ & $\Omega(p)$ & \\
\hline
\end{tabular}

Consider a generic function $y=f(x)$. Its first derivative is written:

- in the common notation: $d f(x) / d x$;

- in Cournot's notation: either $d f(x) / d x$ or $d y / d x$; and

- $\quad$ in Peirce's notation $D_{x} y$.

Table A.2 shows each equation in the paper and its corresponding equation translated into either Cournot's or Peirce's notation as appropriate. 
Table A.2

Correspondence of Equations

\begin{tabular}{|c|c|c|}
\hline Common Notation & \multicolumn{2}{|l|}{ Cournot } \\
\hline equation & equation $^{1}$ & page $^{2}$ \\
\hline (1) $q=F(p)$ & $D=F(p)$ & 47,57 \\
\hline (2) $\Pi=p F(p)-\Phi(q)$ & net receipts $=p F(p)-\phi(q)$ & \\
\hline (3) $\left[F(p)+p \frac{d F}{d p}\right]-\left[\frac{d \Phi}{d q} \frac{d F}{d p}\right]=0$ & see Common Notation ( $3^{\prime}$ ) below & \\
\hline$q+\frac{d F}{d p}\left[p-\frac{d \Phi}{d q}\right]=0$ & $\mathrm{~V}(2) \quad D+\frac{d D}{d p}\left[p-\frac{d[\phi(D)]}{d D}\right]=0$ & 57 \\
\hline (4) $f\left(q_{1}+\bar{q}_{2}\right)+\frac{d f\left(q_{1}+\bar{q}_{2}\right)}{d q} q_{1}-\frac{d \Phi_{1}\left(q_{1}\right)}{d q_{1}}=0$ & $\operatorname{VII}(1) f\left(D_{1}+D_{2}\right)+D_{1} f^{\prime}\left(D_{1}+D_{2}\right)=0$ & 81 \\
\hline (5) $f\left(\bar{q}_{1}+q_{2}\right)+\frac{d f\left(\bar{q}_{1}+q_{2}\right)}{d q} q_{2}-\frac{d \Phi_{2}\left(q_{2}\right)}{d q_{2}}=0$ & $\operatorname{VII}(2) f\left(D_{1}+D_{2}\right)+D_{2} f^{\prime}\left(D_{1}+D_{2}\right)=0$ & 81 \\
\hline (6) $q_{k}+\frac{d F}{d p}\left[p-\frac{d \Phi_{k}\left(q_{k}\right)}{d q_{k}}\right]=0$ & $D_{k}+\left[p-\phi_{k}^{\prime}\left(D_{k}\right)\right] \cdot \frac{d D}{d p}=0$ & 90 \\
\hline (7) $p-\frac{d \Phi_{k}\left(q_{k}\right)}{d q_{k}}=0$ & $p-\phi_{k}^{\prime}\left(D_{k}\right)=0$ & 90 \\
\hline (8) supply $=\Omega(p)=F(p)=$ demand & $\operatorname{VIII}(3) \Omega(p)=F(p)$ & 91 \\
\hline & Peirce & \\
\hline equation & equation & source $^{3}$ \\
\hline$q_{1}+\frac{d F}{d p_{1}} p_{1}=0$ & $y_{1}+D_{x_{1}} y_{1} \cdot x_{1}=0$ & $\mathrm{BP}$ \\
\hline$q_{2}+\frac{d F}{d p_{2}} p_{2}=0$ & $y_{2}+D_{x_{2}} y_{2} \cdot x_{2}=0$ & $\mathrm{BP}$ \\
\hline (11) $\frac{d F}{d p_{1}}=-\infty$ & $D_{x_{1}} y_{1}=-\infty$ & BP \\
\hline $\bar{p}-\frac{d \Phi(q)}{d q}=0$ & $X-D_{y} \mathrm{z}=0$ & $\mathrm{SN}$ \\
\hline (13) $q+\frac{d F}{d p}\left[p-\frac{d \Phi}{d q}\right]=0$ & $y+D_{x} y\left(x-D_{y} z\right)=0$ & SN \\
\hline
\end{tabular}

Notes: ${ }^{1}$ Where equation numbers are indicated, the Roman numeral indicates the relevant chapter in Cournot (1838) and the parenthetical numeral, the actual equation number.

2“number” indicates the page number in Cournot (1838) on which the equation occurs.

3“source” indicates the document in which the equation is found: BP = Peirce's letter to Benjamin Peirce (Peirce 1871d); SN = Peirce's letter to Simon Newcomb (Peirce1871c 


\section{References}

Archibald, Raymond C. (1924) "Simon Newcomb 1835-1909, Bibliography of His Life and Work," in Memoirs of the National Academy of Sciences, vol. 17. Washington, D.C.: U.S. Government Printing Office, pp. 19-69.

Babbage, Charles. (1835) On the Economy of Machinery and Manufactures, $4^{\text {th }}$ edition. London: Charles Knight.

Baumol, William J. and Stephen M. Goldfeld, editors. (1968) Precursors in Mathematical Economics: An Anthology. London: The London School of Economics and Political Science.

Bertrand, Joseph Louis François. (1883) Review of Théorie Mathématique de la Richesse Sociale and Recherches sur les Principes Mathematiques de la Theorie des Richesses, Journal des Savants, Année 1883(9), 499-508 (English translation by James Friedman in Daughety (1988), pp. 73-81.

Blaug, Mark. (1997) Economic Theory in Retrospect, $5^{\text {th }}$ ed. Cambridge: Cambridge University Press.

Brent, Joseph. (1998) Charles Sanders Peirce: A Life, revised and enlarged edition. Bloomington: University of Indiana Press.

Campbell, William W. (1924) "Biographical Memoir of Simon Newcomb, 1835-1909," in Memoirs of the National Academy of Sciences, vol. 17. Washington, D.C.: U.S. Government Printing Office, pp. 1-18.

Carey, Henry C. (1858-1860) Principles of Social Science, vols. 1-3. Philadelphia:

Lippincott.

Cherriman, John Bradford. (1857) Review of Cournot's Recherches sur les Principes Mathematiques de la Theorie des Richesses, Canadian Journal of Industry, Science and Art, N.S. 2, 185-194.

Cournot, Antoine Augustin. (1838) Recherches sur les Principes Mathematiques de la Theorie des Richesses. Paris: Hachette. All quotations are to the English translation: Researches into the Mathematical Principles of the Theory of Wealth, Nathaniel T. Bacon, translator. New York: Macmillan, 1927.

Daughety Andrew F. editor. (1988) Cournot Oligopoly: Characterization and Applications. Cambridge: Cambridge University Press.

de Fontenay, R. (1864) “Principes Mathematiques de la Théorie des Richesses par M. Cournot, Journal des Économistes, 11, 231-251.

Dimand, Robert W. (1995) "Cournot, Bertrand, and Cherriman," History of Political Economy 27(3), 563-78.

Eisele, Carolyn, editor. (1976) The New Elements of Mathematics by Charles S. Peirce. The Hague: Mouton.

Eisele, Carolyn. (1957) "The Charles S. Peirce-Simon Newcomb Correspondence," Proceedings of the American Philosophical Society, 101(5), 409-433. 
Ekelund, Robert B., Jr.; , Robert F. Hébert. "Cournot and His Contemporaries: Is an Obituary the Only Bad Review?” Southern Economic Journal 57(1), 139-149.

Fisch, Max. (1982) “Introduction,” Writings of Charles S. Peirce: A Chronological Edition, vol. 1. Bloomington: Indiana University Press.

Fisch, Max. (1999). “Economy, Political, application of mathematics to,” Max H. Fisch Chronological and Topical Data Slips, Peirce Edition Project, Institute for American Thought. Indiana University Purdue University at Indianapolis (accessed August 1999).

Humphrey, Thomas M. (2010) “Marshallian Cross Diagrams,” in Mark Blaug and Peter Lloyd, editors. Famous Figures and Diagrams in Economics. Cheltenham: Edward Elgar, pp. 29-37.

Isnard, Achille-Nicolas. (1781) Traité des Richesses: Contenant l'Analyse de l'Usage des Richesses en Général et de leurs Valeurs, les Principes et les Loix Naturelles de la Circulation des Richesses, de leur Distribution, du Commerce. Lausanne: François Grasset.

Jenkin, Fleeming (1870). "The Graphic Representation of the Laws of Supply and Demand, and Their Application to Labour," in Alexander Grant, editor. Recess Studies. Edinburgh: Edmonston and Douglas, pp. 151-185.

Jevons, William Stanley. (1871) The Theory of Political Economy. London: Macmillan.

Jevons, William Stanley. (1879) The Theory of Political Economy, $2^{\text {nd }}$ edition. London: Macmillan.

Menand, Louis. (2002) The Metaphysical Club: A Story of Ideas. New York: Macmillan, 2002.

Menger, Carl. (1871) Grundsätze der Volkswirtschaftslehre. Wein: Braumüller

Moyer, Albert E. (1992) A Scientist's Voice in American Culture: Simon Newcomb and the Rhetoric of Scientific Method. Berkeley: University of California Press.

National Academy of Science (undated) "History," web page

(http://www.nasonline.org/about-nas/history/), downloaded 10 May 2012.

N[ewcomb], S[imon]. (1872) Review of The Theory of Political Economy by W. Stanley Jevons, North American Review114(235), 435-440.

Newcomb, Simon. (1886) Principles of Political Economy. New York: Harper \& Brothers.

Newcomb, Simon. (1903) Reminiscences of an Astronomer. New York: Harper Brothers.

Nichol, A. J. (1938) “Tragedies in the Life of Cournot,” Econometrica 6(3), 193-197.

Peirce, Charles S. (1871a) “Calculus of Wealth,” in The New Elements of Mathematics, Carolyn Eisele, ed., vol. III/I, 1976, pp. 551-552, (paper is dated as December 1871 by editors of Writings of Charles S. Peirce: A Chronological Edition, vol. 2, E. C. Moore, et. al., editors, 1984, p. 568).

Peirce, Charles S. (1871b) “[Letter to Melusina Fay Peirce],” in Brent (1998, p. 89). 
Peirce, Charles S. (1871c) “Letter to Simon Newcomb,” in Eisele (1957).

Peirce, Charles S. (1871d) “[Letter to Benjamin Peirce],” in The New Elements of Mathematics, Carolyn Eisele, ed., vol. III/I, 1976, pp. 553-554.

Peirce, Charles S. (1873) “Letter, Peirce to Abraham B. Conger,” Writings of Charles S. Peirce: A Chronological Edition, vol. 3, C. J. W. Kloesel, et. al., editors, 1986. Indiana University Press: Bloomington, pp. 109-10.

Peirce, Charles S. (1874) “[On Political Economy],” Writings of Charles S. Peirce: A Chronological Edition, vol. 3. C. J. W. Kloesel, et. al., editors, 1986. Indiana University Press: Bloomington, pp. 173-76.

Peirce, Charles S. (1884) “The Reciprocity Treaty with Spain,” Writings of Charles $S$. Peirce: A Chronological Edition, vol. 5. C. J. W. Kloesel, et. al., editors, 1993. Indiana University Press: Bloomington, pp. 144-146.

Peirce, Charles S. (1885) “The Spanish Treaty Once More,” Writings of Charles S. Peirce: A Chronological Edition, vol. 5. C. J. W. Kloesel, et. al., editors, 1993. Indiana University Press: Bloomington, pp. 147-148.

Samuelson, Paul A. (1947) Foundations of Economic Analysis. Cambridge, MA: Harvard University Press.

Schumpeter, Joseph A. (1954) A History of Economic Analysis. New York: Oxford University Press.

Shubik, Martin. (1987) “Antoine Augustin Cournot,” in John Eatwell, Murray Milgate, and Peter Newman, editors. The New Palgrave: A Dictionary of Economics, vol. 1. London: Macmillan, pp. 708-712.

Walras, Leon. (1874a) L'application des Mathématiques à L'économie Politique et Sociale, reprint. New York: Lennox Hill (Burt Franklin), New York, 1974

Walras, Leon. (1874b) Éléments d'Économie Politique Pure. Paris: L. Corbaz. Translated into English by William Jaffee as Elements of Pure Economics: Or the Social Theory of Wealth. London: George Allen \& Unwin, 1954. 


\section{Figure 1. Cournot's Monopoly}

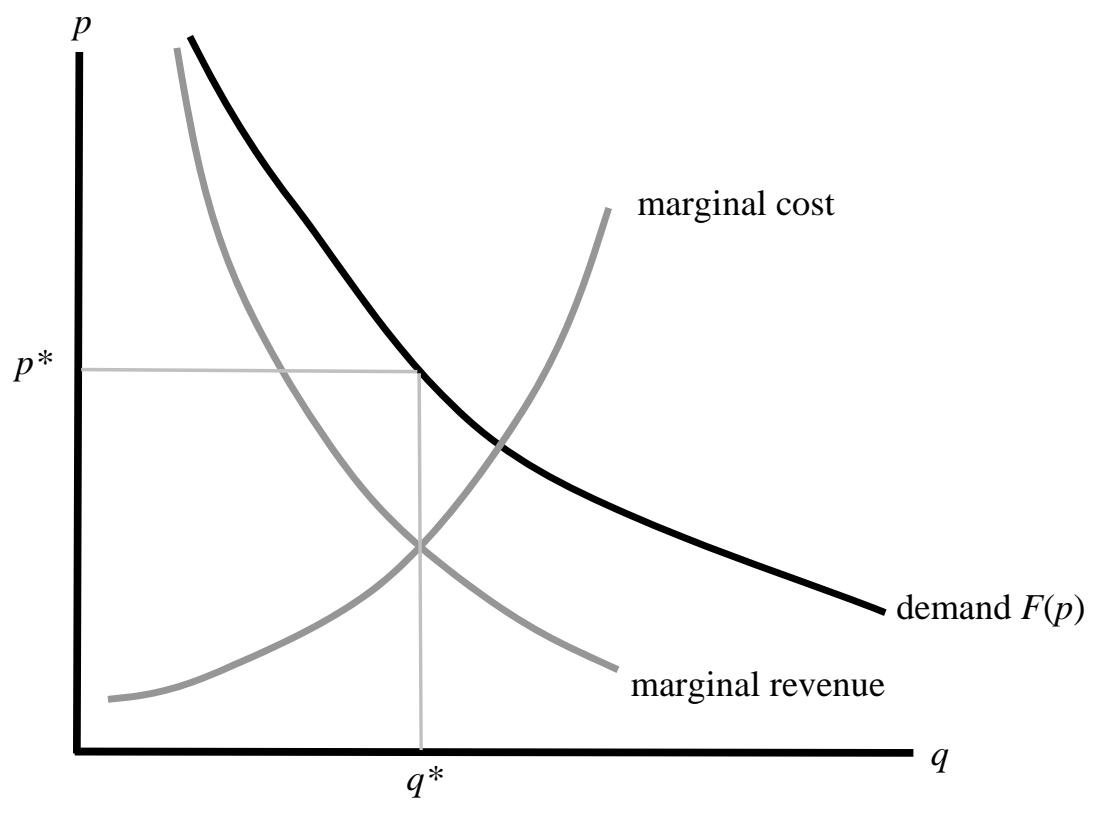


Figure 2. Conjectural Decision-Problem for Cournot's Duopolist

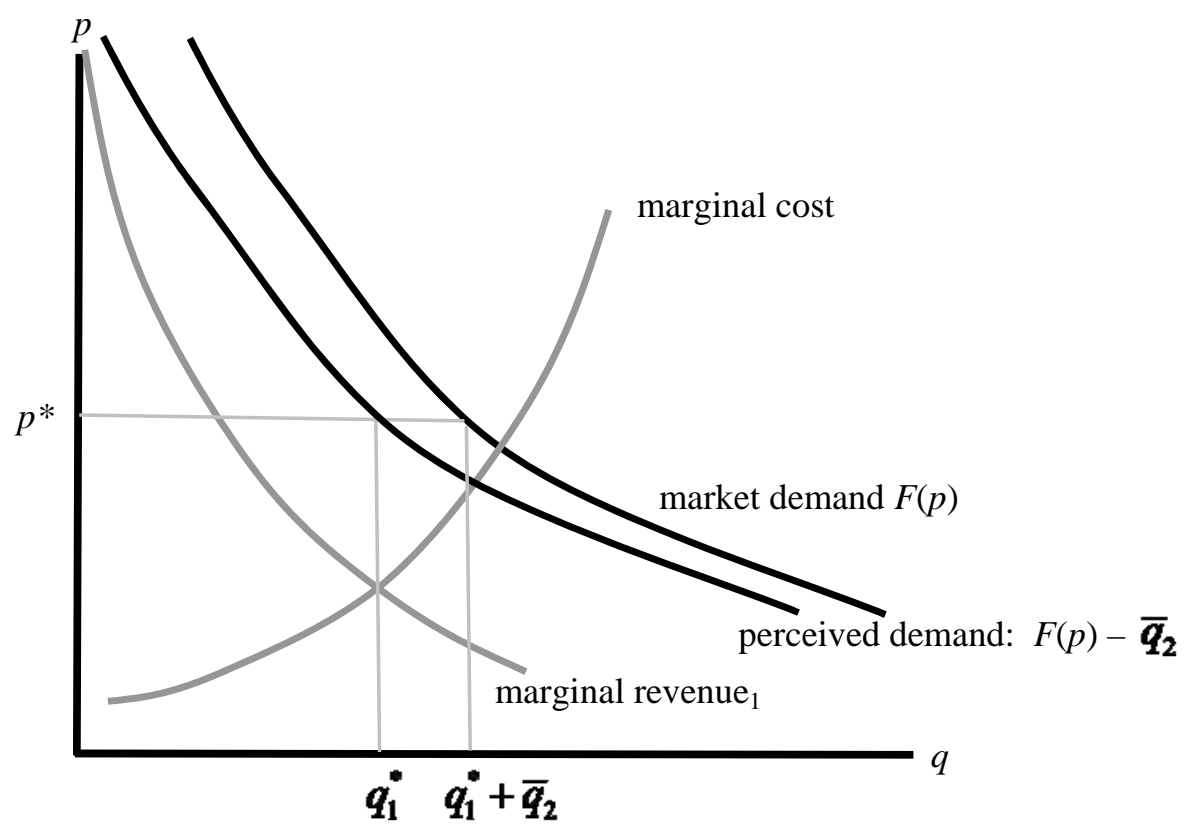




\section{Figure 3. Cournot Duopoly: Reaction Functions}

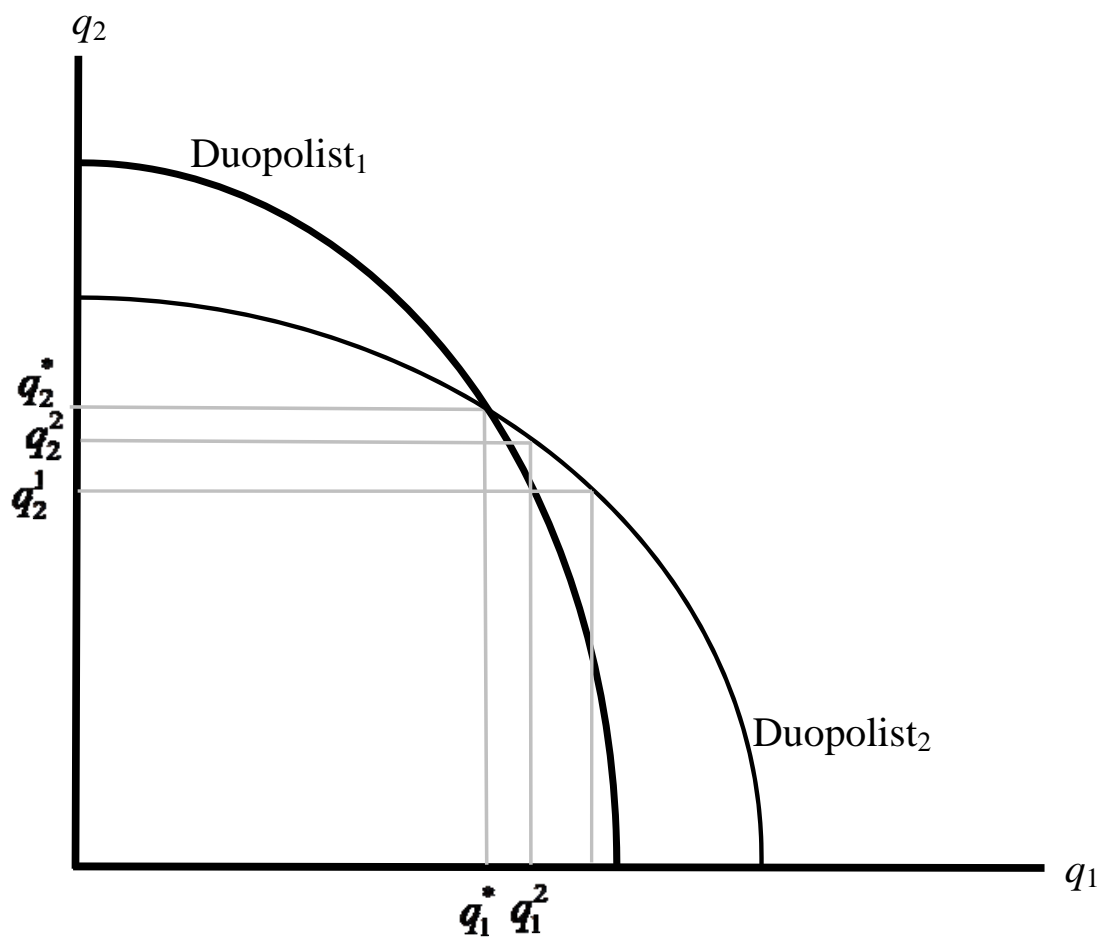


Wible and Hoover

18 July 2013

Figure 4. Cost Curves

A. Total Cost

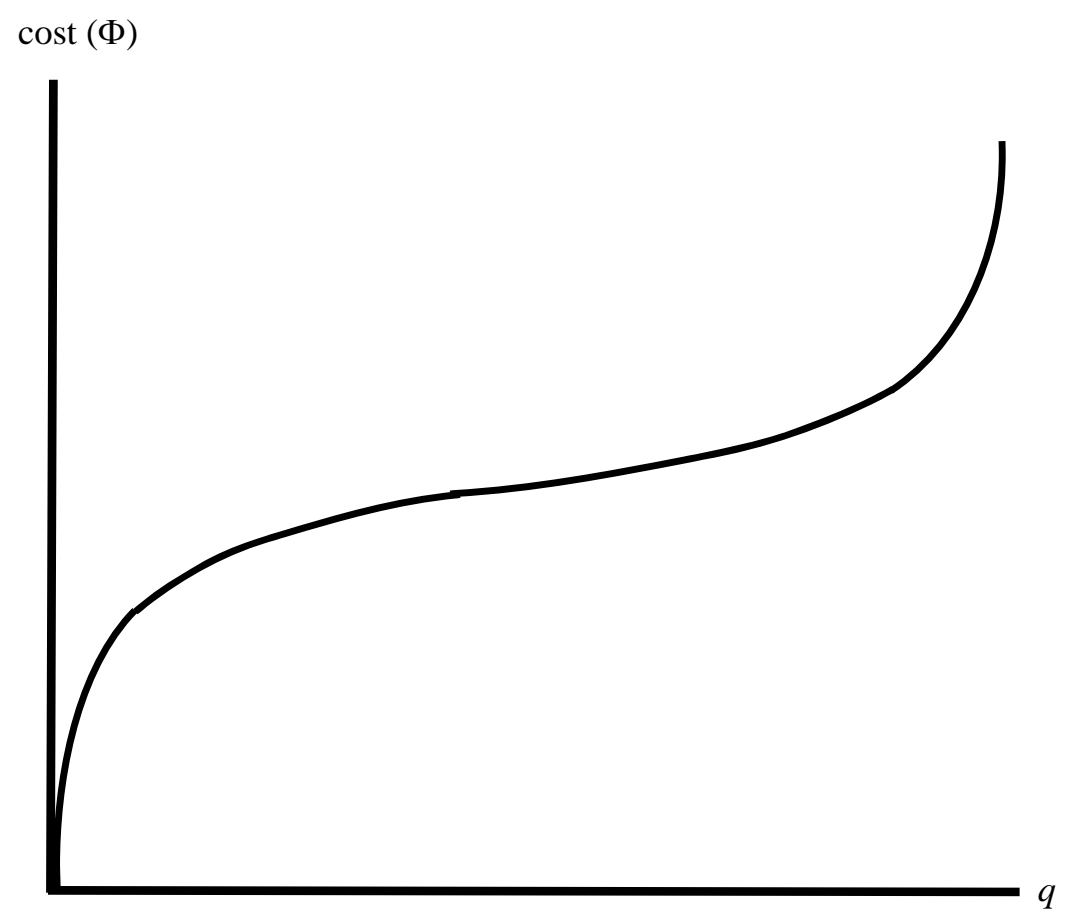

B. Marginal Cost

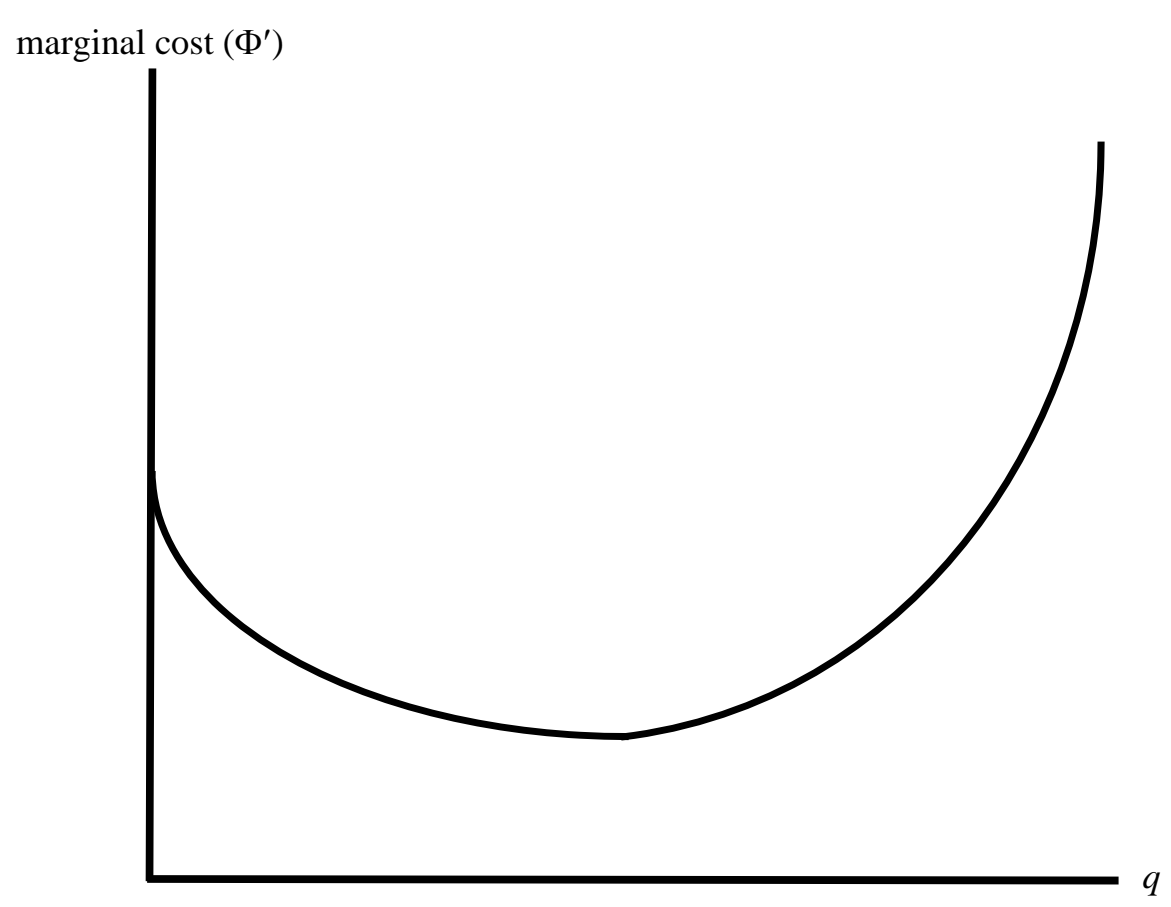

42 


\section{Figure 5.}

\section{An Increase in Demand Can Lower Monopoly Price}

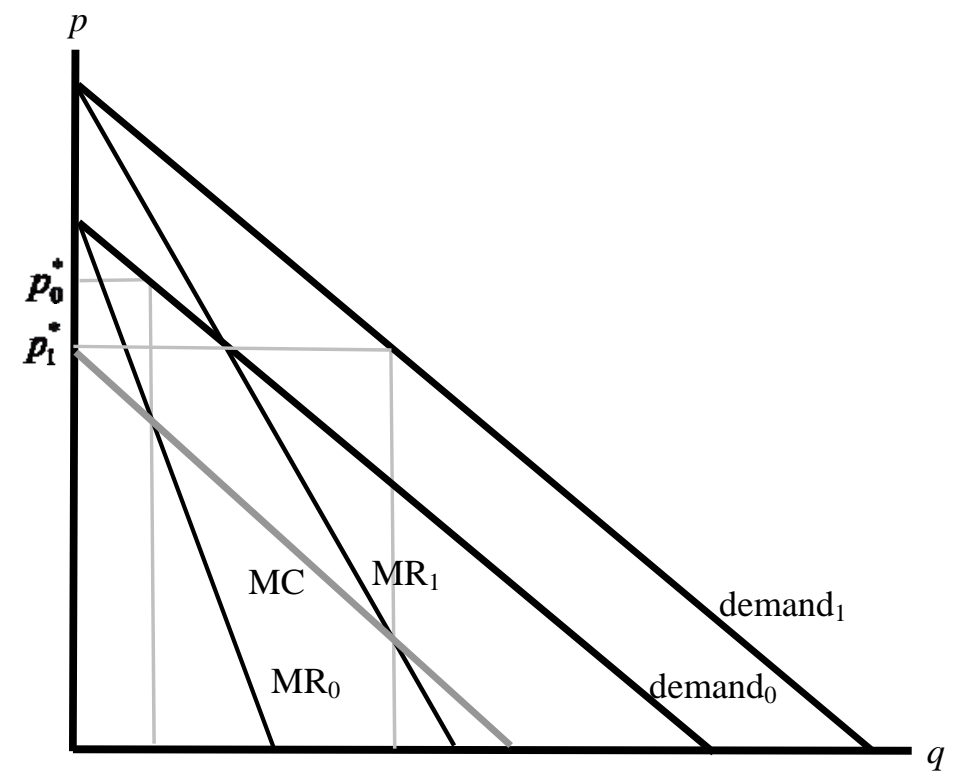

An increase in demand shifting the demand curve from demand $\mathrm{d}_{0}$ to demand $\mathrm{d}_{1}$ and marginal revenue from $\mathrm{MR}_{0}$ to $\mathrm{MR}_{1}$ can reduce the price set by a monopolist from $\boldsymbol{p}_{\mathbf{0}}^{*}$ to $\boldsymbol{p}_{\mathbf{1}}^{*}$ provided marginal cost (MC) falls steeplv enough. 
Figure 6.

Unlimited Competition: The Market and the Individual Producer
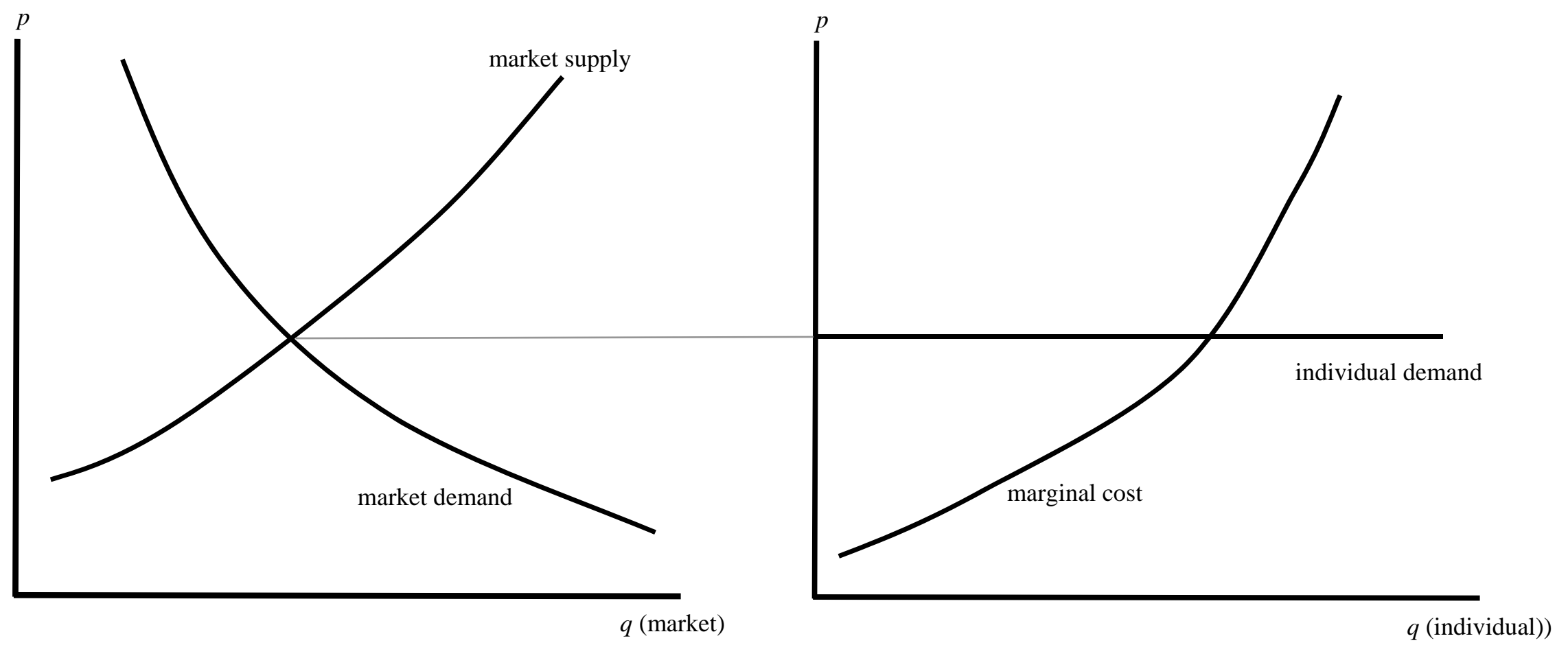